\title{
WIND, SIZE, AND TREE SAFETY
}

\author{
by Karl J. Niklas
}

\begin{abstract}
To persist and survive in any environment, a tree must be mechanically reliable and achieve a reasonable factor of safety. This safety factor, which must be adjusted over the course of plant growth, can be computed for stems and roots based on the quotient of the working load and load-bearing capacity of each organ. This method is illustrated for the stems of cherry trees (Prunus serotina) and for the root systems of an arborescent columnar cactus (Pachycereus pringlei) differing in size. The factor of safety of these organs decreases with increasing plant size. The susceptibility of stems and roots to mechanical failure thus increases as plants grow in mass or height. However, the risk of wind-induced tree failure is reduced in the case of cherry trees by the selective wind-failure of small peripheral branches, which reduces the overall drag forces and bending moments acting on trunks. In the case of the columnar cactus, the demand for root water absorption/ storage may take precedence over anchorage as plants increase in overall size. These two case studies illustrate that manifold factors of safety must be considered and ranked simultaneously in terms of the probability of damage or death for different environmental risk factors.
\end{abstract}

Key Words. Biomechanics; drag forces; safety factors; trees, wind damage.

Much of biology is explicable in terms of the operation of simple physical laws and processes (Wainwright et al. 1976; Vogel 1981; Niklas 1992). The effects of these laws and processes on plants as well as animals are size-dependent (Huxley 1932; Niklas 1994). This is nowhere better seen than in the case of trees. To survive and grow, these long-lived and sedentary organisms must constantly adapt to their changing physical surroundings in which gravity and wind play persistent and important roles (Metzger 1893; King and Loucks 1978; Vogel 1981; Niklas 1998a).

For example, simple physics shows that gravity compresses tree trunks and causes cantilevered branches to bend under their own weight (Wainwright et al. 1976; Niklas 1992). The same simple physics shows that the self-loading stems experience increases in proportion to growth in girth, length, or number such that older portions of stems support increasingly more weight (Niklas 1992, 1994, 1999a). Likewise, as a tree grows and elevates more leaves and stems higher above ground, the drag forces generated by wind pressure acting on these organs increase (Mayhead 1973; Monteith 1973; Vogel 1981; Niklas and Spatz 1999, 2000).

Importantly, these mechanical forces are transmitted to the root system by virtue of trunk bending moments (Niklas 1992; Ennos 1993). It is not surprising therefore that, for its weight per unit volume, wood is the strongest and stiffest plant tissue. Likewise, it is no surprise that twigs and leaves easily deflect or curl in the wind-thus reducing the drag forces they help to create-nor that the geometry of root systems changes in proportion to the loads transmitted by trunks (Vogel 1981; Coutts 1983; Niklas 1992, 1999a; Ennos 1993, 2000).

Given the extreme complexity of tree architecture and the vagaries of their physical environment, a precise description of how trees adapt to gravity or wind and thus avoid or delay excessive damage or death remains elusive. However, one important approach to describing adaptive tree morphology is to explore stem and root "safety factors" and to examine how these expressions of mechanical reliability change with increasing size (Mattheck et al. 1993; Niklas 1998b, 2000; Niklas et al. 1999). Although it is firmly entrenched in the engineering literature, the "safety factor" concept is not deeply ingrained in the biological sciences, yet it provides a relatively easy method to compare how organisms differing in size, shape, or geometry cope with their physical surroundings. Indeed, this approach can be surprisingly instructive, even in terms of practical horticultural concerns such as the effects of pruning on mechanical stability.

\section{THE SAFETY FACTOR CONCEPT}

The concepts of safety and reliability are linked. A safe structure functions reliably under the conditions it normally experiences. A safer structure functions reliably under conditions that exceed normal working conditions. The extent to which a structure accommodates unusual working conditions is quantified by the factor of safety. In engineering, this factor is traditionally computed by dividing the load-bearing capacity of a structure or mechanism by its working load (Johnson 
1961; Meredith et al. 1973; Leitch 1975). The working (actual) load is the force that a structure normally bears. The load-bearing capacity is the maximum force that the same structure can support without permanently deforming or breaking.

Other measures of reliability can be used to specify the factor of safety. For example, the quotient of a structure's bending (or torsional) stress capacity and its corresponding bending (or torsional) working stress can be used to compute the safety factor. Likewise, the quotient of a moment capacity and the working moment, or the quotient of critical buckling height and actual height, can be used. But, regardless of the features used to compute mechanical reliability, the safety factor invariably reflects some specified criterion for failure-that is, some expectation of how a structure is most likely to fail mechanically.

Clearly, the minimum safety factor is one. A structure with a factor of safety less than unity is unreliable even for the working conditions it would normally experience. This lower limit may define the cheapest cost of construction, but it invariably defines the workably least safe structure. With few exceptions, structures must have safety factors much greater than one, because every environment can be unpredictable and because structures mechanically fatigue as they age.

In contrast to a well-defined lower limit, the upper limit or "ceiling" for a particular structure's factor of safety is problematic. It depends on a variety of factors that must be evaluated both in terms of the probability and the consequences of failure (Wainwright et al. 1976). What is the risk that a structure will fail? What are the most likely consequences of failure? These and other questions are typically used by engineers to specify a priori the factor of safety for a particular structure. Unlike engineers, plants are incapable of making these evaluations. Nonetheless, natural selection provides the venue for "risk and cost management." Organisms with marginal factors of safety will have a higher probability of dying or reproducing less well than those with higher safety factors. Likewise, organisms with very high factors of safety may be excessively "overbuilt" and thus squander valuable resources that could be otherwise invested in growth or reproductive effort. Importantly, natural selection cannot anticipate future environmental changes but, over successive generations, it can provide a retrospective "flywheel" that calibrates the safety factor in terms of the risks and costs a species typically encountered.
Because individuals of sexually reproducing species genetically differ, the effects of natural selection on factors of safety must be evaluated at the level of populations (Niklas 1990a,b; 1998a; Niklas et al. 1999). In this respect, the mechanical capacities of individual trees are known to differ even among individuals of the same size and general appearance. Some trees may produce wood that is intrinsically weaker or stronger than other conspecifics just as some engineering production lines produce materials of varying quality during the same run of production (Weibull 1939; Niklas 2000). A population of plants will typically exhibit a range of safety factors, with a frequency distribution manifesting a Weibull frequency distribution. The significance of this distribution is that there are always a few individuals that have high factors of safety such that they will likely survive and perpetuate the species locally after an environmental crisis.

Yet another important consideration is that most plants have a modular construction. That is, they are composed of repeated interconnecting functional units (e.g., shoots and roots) that can have very different load-bearing capacities as a result of growth vagaries or prior damage. The working conditions even of seemingly identical body parts can also differ as a result of micro-environmental conditions (Niklas 1999b). Stems growing in sheltered locations within the same tree canopy can have lower load-bearing capacities than those growing in exposed locations, because plants respond thigmomorphogenetically to local conditions. That is, individual organ morphology and tissue material properties vary in accordance with the degree of mechanical perturbation (Niklas 1992).

It cannot escape attention that these and other features of plant biomechanics have an obvious bearing on everyday matters of pruning. When stems are exposed by the removal of neighboring portions of a tree, previously sheltered and mechanically reliable body parts may deform or break even under wind conditions that are "normal." Pruning also shifts the self-loading conditions of branches or roots. This can stimulate compensatory changes in the growth of other body parts to reacquire overall mechanical stability and reliability. But, during the interim of growth, devastating effects can occur.

Yet, in practical terms, it is comparatively easy to measure the load-bearing capacity of organs or entire trees. Individual specimens can be sacrificed and tested in the laboratory to construct a statistical "picture" of organ load-bearing capacities. This is how engineers 
typically determine the quality of a production line of steel, aluminum, or nylon thread (Leitch 1975). However, engineers have an advantage over the biologist because they know the working conditions of fabricated structures and typically specify the working conditions. In contrast, the biologist must determine the working loads or stresses that organisms sustain, since the conditions of the "workplace" can vary dramatically, especially for long-lived organisms such as trees. Nonetheless, we can either determine empirically or estimate the general conditions of the workplace, even for large plants. Wind, ice, and snow loadings can be measured on a day-byday or season-by-season basis for a particular site. Alternatively, we can specify a priori the maximum loading conditions that are likely to occur in order to calculate acceptable factors of safety for individual trees growing in particular locations.

Two examples, given below, illustrate how factors of safety can be determined for trees. In each case, the environmental factor of interest is wind because the drag forces produced by wind pressure are the most prevalent worldwide physical forces causing plant mechanical failure.

\section{STEM SAFETY FACTORS}

This example comes from a study of Prunus serotina trees differing in size and shape, all growing in the same open terrain (Niklas and Spatz 2000). The largest and oldest of these trees measured $13.11 \mathrm{~m}$ (43 ft) in height; the smallest measured $0.29 \mathrm{~m}(0.95 \mathrm{ft})$ in height (Figure 1). Working stresses and stress capacities were used to quantify the factors of safety of the stems of these trees. A bending stress is denoted by $\sigma$. It equals the bending force $F$ acting per unit stem crosssectional area $A$. Thus, $\sigma=F / A$. Since the bending force induced by wind pressure is normalized with respect to stem size, the working (actual) bending stress $\sigma_{\text {work }}$ and the bending stress capability (the maximum stress that a stem can sustain) $\sigma_{\text {cap }}$ are independent of stem cross-sectional area such that the factor of safety is given by $\sigma_{\text {cap }} / \sigma_{\text {work }}$.
To calculate safety factors, the working stresses of stems were estimated by measuring wind speeds simultaneously in the field at 1-m intervals along the height of the tallest tree. This provided the vertical wind speed profile that the tree normally experienced (Figure 2). This wind profile and the surface areas projected by stems toward the wind were then used to calculate the drag forces exerted on stems at different locations in the infrastructure of each tree. Stem projected areas were measured by digitizing photographs of each of the trees; computer software was used to calculate stem projected areas. Using these data, the working stresses of stems differing in size and location were estimated. For the largest tree, the maximum working stresses occurred at the base of the trunk. For the smallest and youngest tree, working stresses varied little as a function of tree height (Figure 3A).

The stress capabilities of representative stems were then measured in the laboratory by bending small and medium-sized stems and measuring the largest stresses

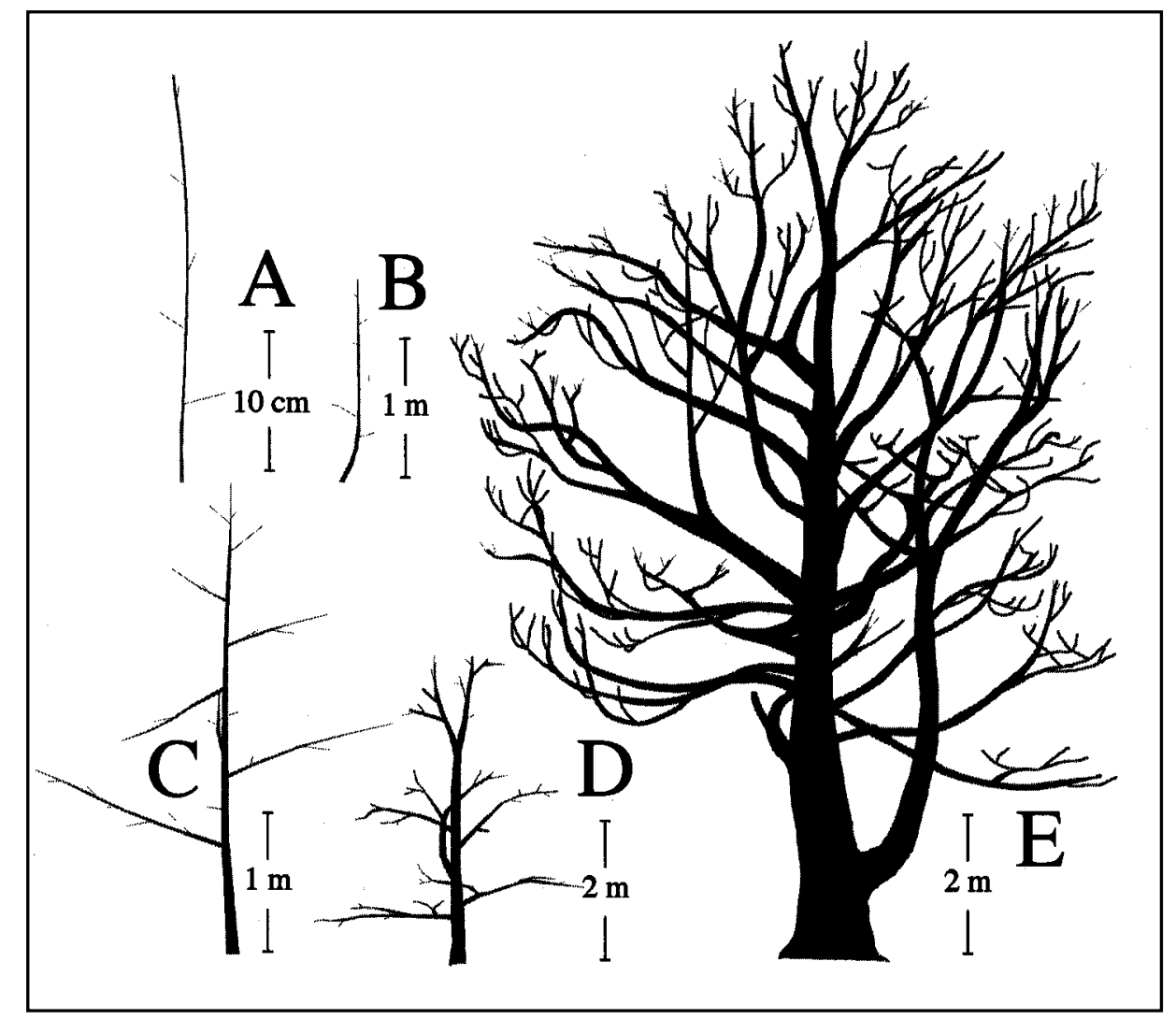

Figure 1. General appearance of five cherry trees (Prunus serotina) in the leafless condition, differing in size and age. Projected surface areas of stems used to compute stem stress induced by wind drag forces (see Figure 3A). Adapted from Niklas and Spatz (2000). 


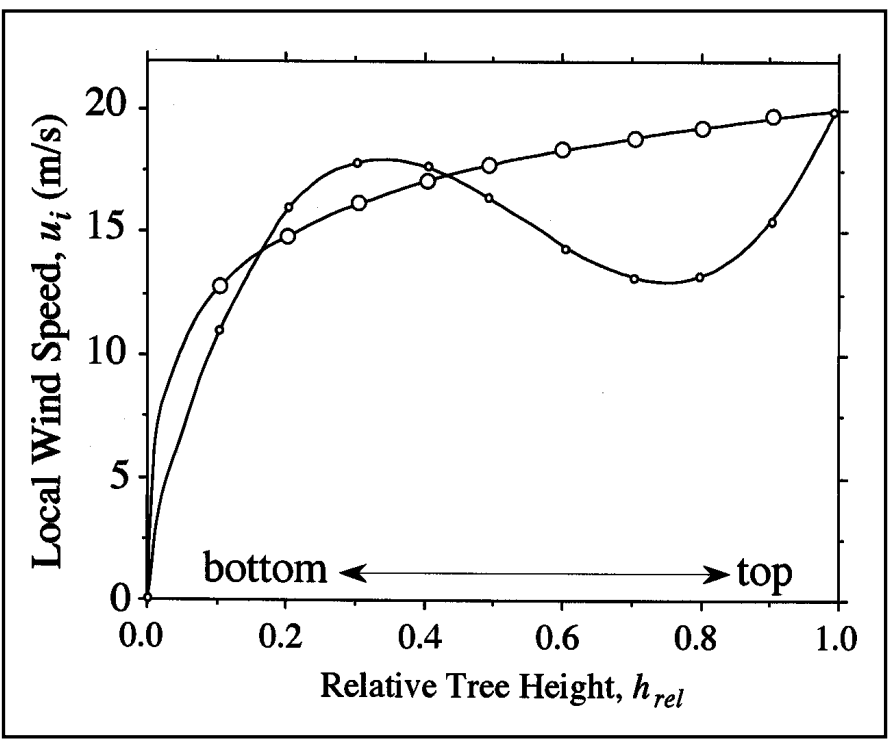

Figure 2. Measured and computed vertical wind speed profiles for the largest of the five cherry trees (see Figure 1E). Sinusoidal profiles based on simultaneous wind speed measurements at 1-m intervals along the length of the trunk. Logarithmic profile computed to provide a comparison. Adapted from Niklas and Spatz (2000).

that each could sustain before breaking or deforming permanently. For very large stems, prismatic beams of wood were surgically removed and tested in bending. Using this protocol, the stress capability of stems differing in cross-sectional area was found to increase from trunk base of the largest tree toward successively smaller stems and twigs (Figure 3B). In general, smaller stems were composed of more flexible plant tissues than progressively larger stems. Smaller stems thus had higher stress capabilities than larger stems.

When plotted as a function of position within individual trees, the factor of safety against wind-induced stem damage varied for each tree but decreased overall with increasing tree size (Figure 4). The susceptibility to wind damage overall thus increased with increasing plant age and height. However, different-sized stems on the same tree had different probabilities of mechanical failure. This "heterogeneity" in the factor of safety was most evident for the largest of the five trees that was predicted to mechanically fail either near its base or toward the peripheral stem elements of its canopy.

This example illustrates a number of important points. Factors of safety can vary significantly among plants differing in size and they can also vary, often dramatically, within the architectural infrastructure of an in-

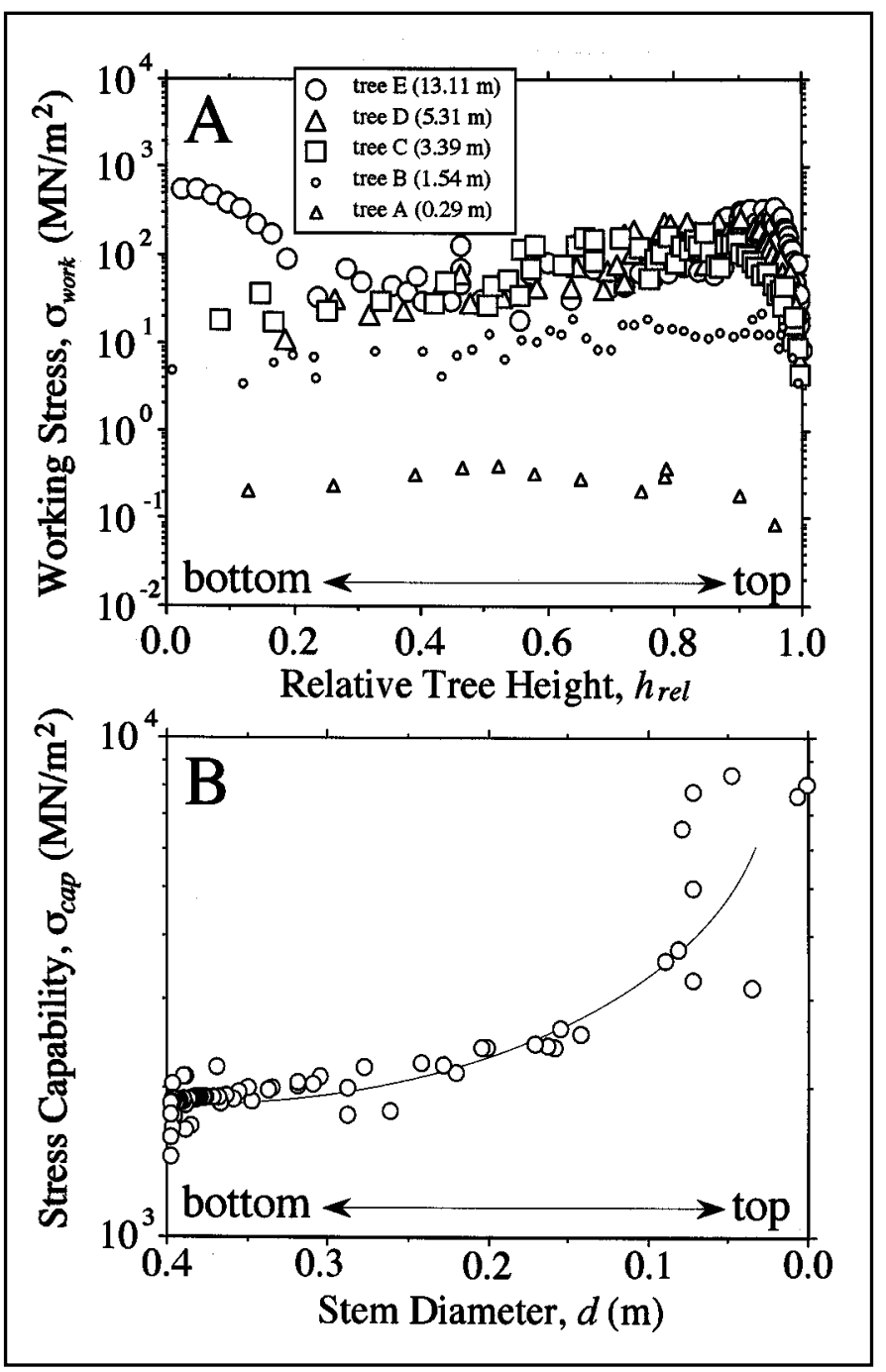

Figure 3. Working wind-induced bending stresses for five cherry trees differing in size (see Figure 1) plotted as a function of relative location of stems in tree architecture (A). Bending stress capacities of representative stems or surgically removed wood samples from the largest of the five trees (see Figure 1E) plotted as a function of relative location of stems in tree architecture (B). Adapted from Niklas and Spatz (2000).

dividual plant. The variation in the factor of safety among individual plants is probably adaptive in terms of a species. Under extremely windy conditions, some plants will mechanically fail and die. These plants are likely to be the oldest rather than the younger individuals in the population. Because younger plants in the same population have very high factors of safety, they will survive, reproduce, and perpetuate the species in the same location even under extreme wind-loading conditions. In this way, the frequency distribution of 


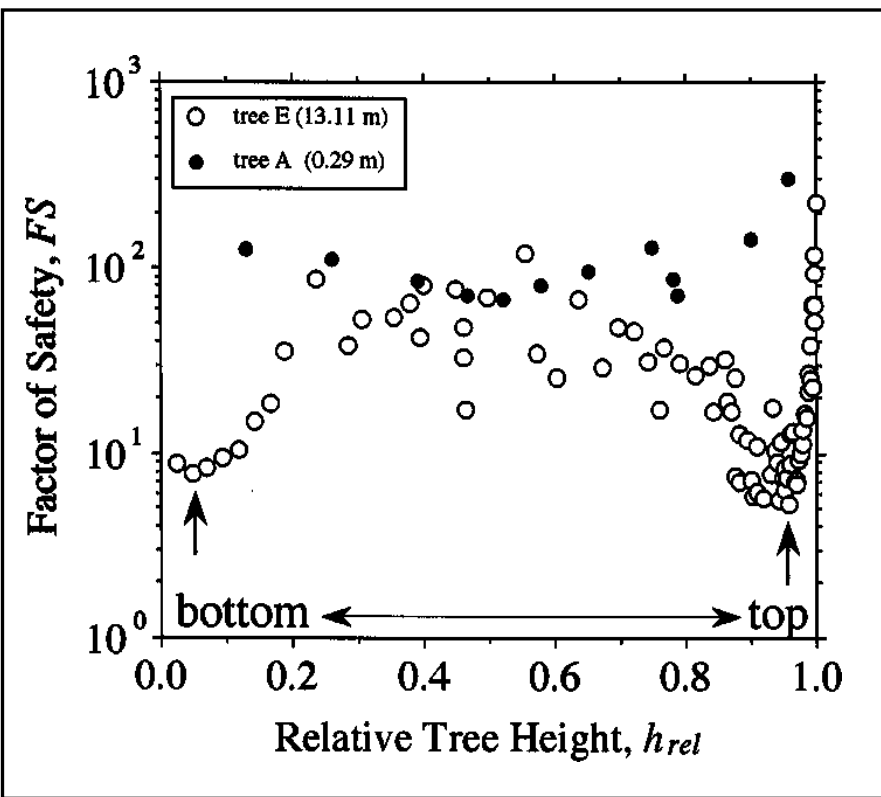

Figure 4. Factors of safety (working bending stress/ stress capability) for stems differing in location along the relative heights of the smallest and largest of the five cherry trees. Arrows denote stem elements with the lowest factors of safety for the largest tree examined. Adapted from Niklas and Spatz (2000).

factors of safety provides an estimate of the survival capacity of a species in a particular site.

Curiously, this example also shows that the survival of small and young plants need not involve high "construction costs." The youngest trees examined were not "overbuilt." Their stems were simply more flexible, in part because secondary and more inflexible tissues (bark and wood) had insufficient time to accumulate even in the oldest parts of the plant.

It also cannot escape attention that even old trees have an adaptive mechanism to avoid death. For the oldest cherry tree, failure can occur in two ways. The trunk can break or the tree can shed a constellation of much smaller and more easily replaced stems and twigs. Trunk failure is likely to cause death, but shedding small stems bearing leaves reduces the drag forces and thus the bending moment exerted at the base of the trunk, thereby reducing the probability of death (Niklas 1999b; Niklas and Spatz 2000).

\section{ROOT SAFETY FACTORS}

The second example of calculating factors of safety is drawn from a recent study of the root biomechanics of the arborescent cactus species Pachycereus pringlei (Niklas et al. 2002). This species is characterized by producing large, vertical, fleshy stems supported at their base by deep bayonetlike roots and laterally extensive but shallow systems of lateral roots (Figure 5).

Comparisons among individuals differing in height indicate that the bayonetlike root extends in depth at a noncommensurate rate with respect to growth in plant height, even though the lateral root system continues to grow outward from the base of plants (Figure 6). From a mechanical perspective, the size-dependent inequality in root and stem growth presents a potential disadvantage in terms of anchorage because the ability of the bayonetlike root to mechanically resist wind-induced stem bending moments depends on the depth of burial of the bayonetlike root (Figure 7A). In the absence of mechanical assistance from lateral roots, this root will pivot near its mid-length as the stem it supports experiences a bending moment, denoted here as $M_{B}$. The rotational pivoting of the root is resisted by the soil surrounding it, which results in a counter-resisting moment, symbolized by $M_{R}$. The deeper the root, the greater the soil resistance. The taller the stem, the larger the bending moment. Therefore, if stems grow faster in height than roots grow in depth, the probability of anchorage failure increases.

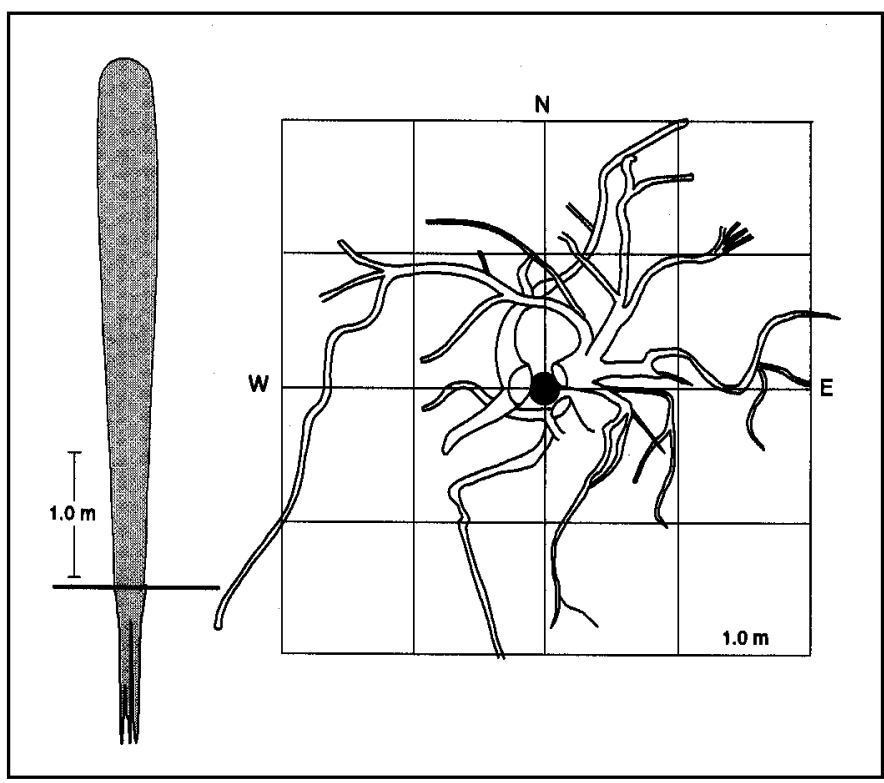

Figure 5. Lateral and polar views of the stem (left) and root system (right) of a large specimen of the columnar cactus species Pachycereus pringlei. Location of stem with respect to root system denoted by black circle. Adapted from Niklas et al. (2002). 


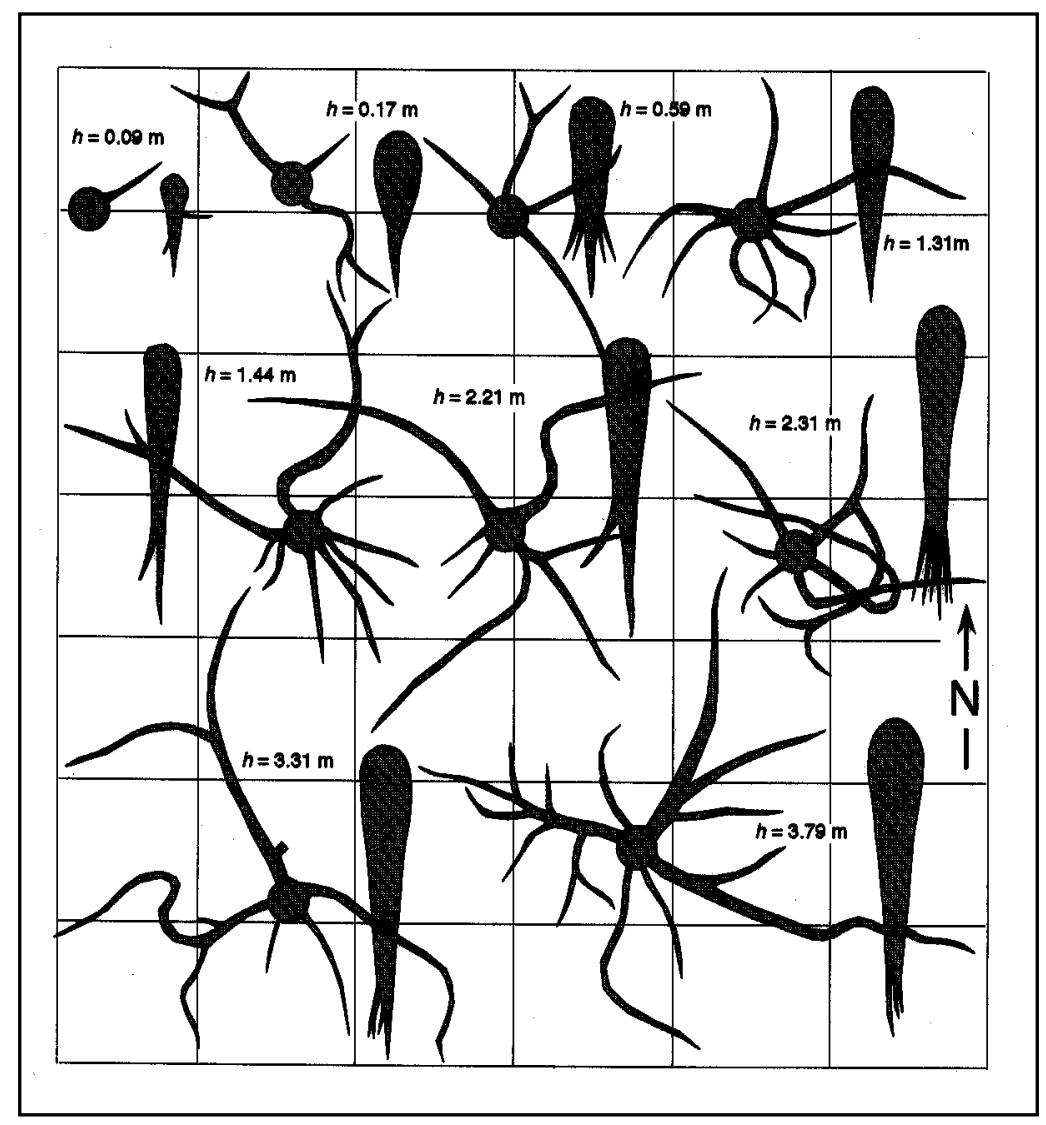

Figure 6. Lateral and polar views of the stems and root systems of specimens of the cactus species Pachycereus pringlei differing in size. Adapted from Niklas et al. (2002).

This situation remains unchanged even if lateral roots mechanically assist in anchorage. The lateral roots will restrain the moment of the bayonet root and elevate the pivot point toward the soil surface. The optimal condition is a pivot point at ground level, since this maximizes soil resistance and thus $M_{R}$ (Figure 7B). However, regardless of the pivot point's location, the factor of safety against root failure is given by the quotient $M_{R} / M_{B}$.

The numerical value of $M_{R}$ is easily calculated, provided we know the size and depth of the bayonet root. These features were measured for 18 P. pringlei plants differing in overall size. The stem bending moment $M_{B}$ is also easily calculated if we know the surface area a stem projects toward the wind as well as the vertical wind speed profile it experiences. Stem projected surface areas were measured for the same 18 cactus plants using photographs. In the particular study reviewed here, the wind speed profile was estimated assuming a logarithmic wind speed profile with a maximum wind speed of $20 \mathrm{~m} / \mathrm{s}(\sim 45 \mathrm{miles} / \mathrm{hr})$ at $5 \mathrm{~m}(\sim 16 \mathrm{ft})$ above ground (Niklas et al. 2002). All 18 plants were assumed to coexist in the same physical environment to compare their ability to resist windthrow.

Using this protocol, calculations indicated that the counter-resisting moments produced by the bayonetlike roots of younger and thus short plants significantly exceed the stem bending moments produced by wind. However, with increasing overall plant size, stem bending moments increased at a rate greater than that of root counter-resisting moments (Figure 8A). Therefore, the factor of safety against windthrow decreased with increasing stem height, and larger plants were more likely to mechanically fail than smaller ones (assuming the same physical environment).

But what is the maximum wind speed that a particular plant can sustain and still remain safely anchored? Put differently, what is the maximum wind speed required to yield the minimum safety factor $M_{R} / M_{B} \sim 1.0$ ? For the largest (tallest) among the 18 plants in this study, the maximum wind speed was $\sim 25 \mathrm{~m} / \mathrm{s}(\sim 56 \mathrm{mi} / \mathrm{hr})$, assuming that lateral roots did not function mechanically to support the stem such that the bayonetlike root pivots at its mid-length (Figure 8B). Higher yet safe maximum wind speeds would be predicted if lateral roots assisted in stem anchorage, because the bayonetlike root would pivot closer to ground level, thereby increasing the resistance of the soil and the overall root counter-resisting moment.

Interestingly, meteorological data (collected between January 1980 and October 1999 by the Comision Nacional del Agua for Empalme, which is located at the southern limit of where these cacti grow in Sonora, Mexico) indicate that maximum wind speeds do not exceed $26 \mathrm{~m} / \mathrm{s}(\sim 58 \mathrm{mi} / \mathrm{hr})$. Therefore, regardless of the location of the root pivot point of the largest cactus, all 18 plants would be predicted to be safe from windthrow. However, field studies of $P$. pringlei plants indicate that many old and tall plants mechanically fail in areas that periodically experience wind speeds exceeding $26 \mathrm{~m} / \mathrm{s}(58 \mathrm{mi} / \mathrm{hr})$ measured at $5 \mathrm{~m}(16.4 \mathrm{ft})$ above ground. As predicted, most of these large plants uproot, although some break at their trunk base and rot where they stand. 


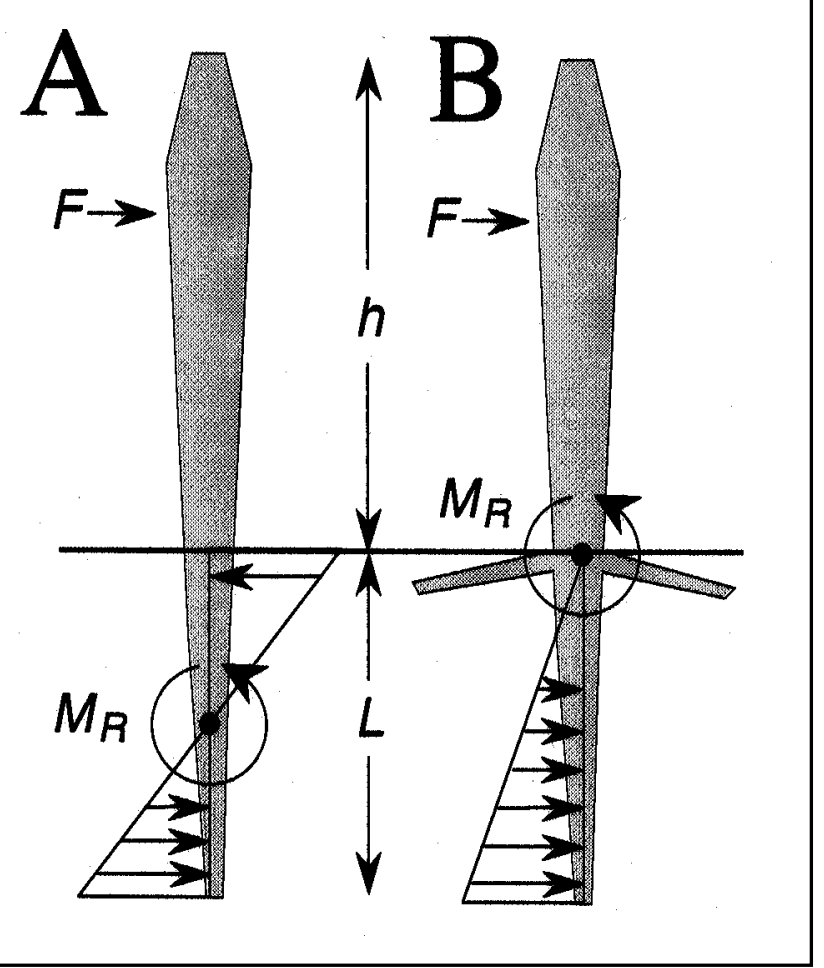

Figure 7. Mechanical features governing root anchorage stability of a stereotypical Pachycereus pringlei plant with stem height $h$ and bayonetlike root depth $L$. Ground level denoted by horizontal line. Wind-induced bending force $F$ causes stem flexure and bayonetlike root pivoting at $L / 2$ in the absence of lateral root restraint (A) or at $L$ if lateral roots act as tensile guy-wirelike mechanical elements (B). In either case, soil surrounding the root resists root pivoting by applying lateral forces against root with increasing intensities away from pivot point (indicated by horizontal arrows). The root thus provides a counter-resisting moment $M_{P}$ to stem flexure. See text for further details. Adapted from Niklas et al. (2002).

\section{CONCLUDING REMARKS}

The trend of decreasing safety factors with increasing plant size in the two foregoing examples may seem counter-intuitive. It certainly challenges the assumption that windthrow is the appropriate criterion with which to gauge safety factors. This draws attention to the fact that there are many equally plausible and biologically realistic criteria that could have been selected to evaluate the safety factors of trees.

Indeed, roots and stems function in manifold ways, each of which is equally important to the growth, survival, and reproductive success of an individual plant (absorption, transport, support, anchorage, storage, metabolism,

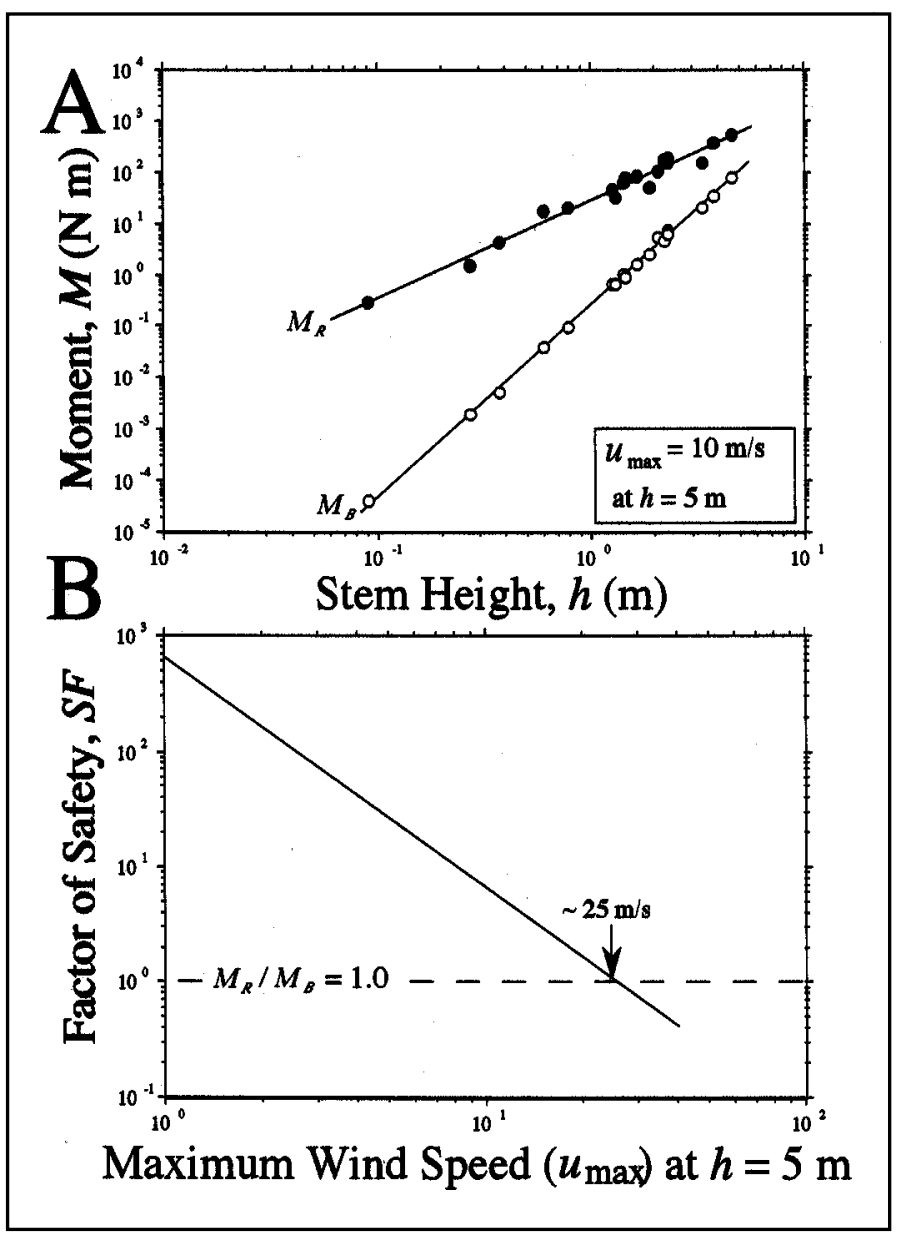

Figure 8. Stem bending moments $M_{B}$ and bayonetlike root counter-resisting moments $M_{R}$ plotted as a function of stem height for 18 Pachycereus pringlei plants differing in size (A). $M_{B}$ computed assuming a maximum wind speed of $10 \mathrm{~m} / \mathrm{s}$ at a distance of $5 \mathrm{~m}$ above ground for each plant (see inset). $M_{R}$ computed assuming that bayonetlike root pivots at $L / 2$ (see Figure 7A). Factor of safety $S F$ for the largest of the 18 plants (see Figure 5) plotted against different maximum wind speeds $u_{\max }$ measured at $5 \mathrm{~m}$ above ground. Dashed horizontal line denotes minimum factor of safety $\left(M_{B} / M_{R}=1.0\right)$, which is predicted to occur when $u_{\text {max }} \sim 25 \mathrm{~m} / \mathrm{s}$. Adapted from Niklas et al. (2002).

meristematic production of new organs, etc.). These manifold functions often require tradeoffs in terms of the performance of any one function. Therefore, it is somewhat naive to assume that any one of these functional obligations is the most critical to survival or success and can thus serve as the single criterion with which to evaluate the factor of safety. A far more realistic and profitable approach to evaluating factors of safety is to first fastidiously assess 
all reasonable performance criteria and then rank all in terms of the probability failure. This protocol requires exhaustive work both in the field and laboratory, but it is essential for evaluating which physical or biological factors dictate plant survival and reproductive success.

For example, in addition to providing anchorage, the roots of $P$. pringlei are important water-storing organs (Niklas et al. 2002). For this species, all root types retain a persistent living cortex and produce wood with a sizeable volume fraction of living ray tissues that serve as a waterstorage compartment, which increases with overall plant size. Additionally, the surface area of suberized old roots (which produce ephemeral absorbing roots) dramatically increases with increasing overall plant size. Indeed, all of the available data indicate that as $P$. pringlei plants grow in size, the functional priorities of their root systems shift such that anchorage becomes less important than water storage and absorption. In an arid and hot environment, this shift is arguably adaptive in an environment where windthrow failure is far less likely than death by dehydration.

The biology of trees illustrates yet another important lesson when considering factors of safety. The rate at which most trees grow in size and elevation gradually decreases with increasing age and overall size (Figure 9). This general phenomenon is functionally adaptive, because it extends the time to windthrow failure, thereby increasing the working lifetime of each tree. Death is inevitable. But the longer an organism lives, the more opportunity it has to reproduce and perpetuate its kind. By the same token, the erosion of the factors of safety (for static or dynamic loadings) with increasing plant size is beneficial in terms of population biology, because the death of the oldest individuals in a population allows for the recruitment of juveniles. This turnover in a local population

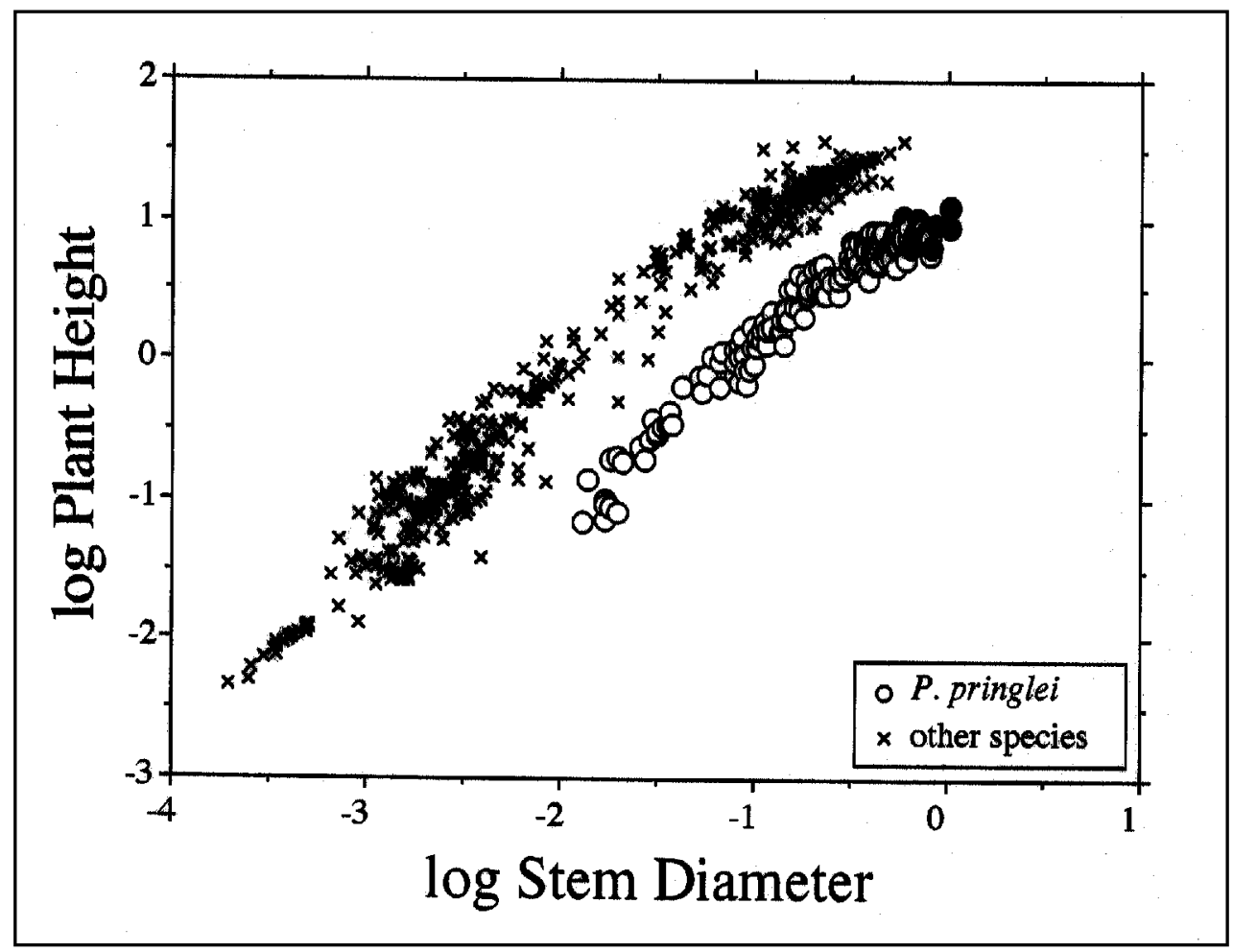

Figure 9. Maximum plant height plotted as a function of basal stem diameter for a variety of dicot, monocot, and gymnosperm species. The overall trend is log-log nonlinear, indicating that the rate of growth in height with respect to growth in stem diameter decreases with increasing plant size (and age). The data for the cactus Pachycereus pringlei appear "shifted" downward and to the right. This likely reflects the "succulence" (and excessive weight) of stems containing a larger-volume faction of living tissues than nonarid-adapted arborescent species. Black dots denote data collected from dead windthrown cacti. 
perpetuates genetic diversity, which is essential for adaptive evolution.

The concept of safety factors is deeply ingrained in a conceptually rich engineering literature. It is also slowly but assuredly emerging as an equally important tool for understanding the vibrant complexity of tree biology and population ecology. Likewise, by virtue of their extensive fossil record, tree species are useful organisms with which to explore the evolution of factors of safety (Niklas and Speck 2001). Although much remains to be learned, both in terms of computing factors of safety and how these factors vary across different organisms and environments, plant biologists and evolutionists are gaining new insights into what "biomechanical reliability" really means.

\section{LITERATURE CITED}

Coutts, M.P. 1983. Root architecture and tree stability. Plant Soil 71:171-188.

Ennos, A.R. 1993. The scaling of root anchorage. of Theoret. Biol. 161:61-75.

- 2000. The mechanics of root anchorage. Adv. Bot. Res. 33:133-157.

Huxley, J.S. 1932. Problems of Relative Growth. Methuen and Comp., Ltd., London, England. 276 pp.

Johnson, R.C. 1961. Optimum Design of Mechanical Elements. John Wiley and Sons, Inc., New York, NY.

King, D., and O.L. Loucks. 1978. The theory of tree bole and branch form. Radia. Environ. Biophys. 15:141-165.

Leitch, R.D. 1975. Reliability Analysis for Engineers: An Introduction. Oxford University Press, Oxford, England. 230 pp.

Mattheck, C., K. Bethge, and J. Schäfer. 1993. Safety factors in trees. J. Theoret. Biol. 165:185 -189.

Mayhead, G.J. 1973. Some drag coefficients for British forest trees derived from wind tunnel studies. Agricul. Meteorol. 12:123-130.

Meredith, D.D., K.W. Wong, R.W. Woodhead, and R.H. Worthman. 1973. Design and Planning of Engineering Systems. Prentice-Hall, Inc., Englewood Cliffs, NJ. 393 pp.

Metzger, K. 1893. Der Wind als massgebender Faktor für das Wachstum der Bäume. Mündener Forstliche Hefte 3:35-86.

Monteith, J.L. 1973. Principles of Environmental Physics. Elsevier, New York, NY. 123 pp.
Niklas, K.J. 1990a. Safety factors in vertical stems: Evidence from Equisetum hyemale. Evolution 43:1625-1636.

- 1990b. Determinate growth of Allium sativum peduncles: Evidence of determinate growth as a design factor for biomechanical safety. Am. J. Bot. 77:762-771.

- 1992. Plant Biomechanics: An Engineering Approach to Plant Form and Function. University of Chicago Press. Chicago, IL. 607 pp.

- 1994. The allometry of safety-factors for plant height. Am.J. Bot. 81:345-351.

- 1998a. The influence of gravity and wind on land plant evolution. Rev. Palaeobot. Palynol. 102:1-14.

- 1998b. A statistical approach to biological factors of safety: Bending and shearing in Psilotum axes. Ann. Bot. 82:177-187.

. 1999a. Variations of the mechanical properties of Acer saccharum roots. J. Exp. Biol. 50:19 -200.

-1999b. Changes in the factor of safety within the superstructure of a dicot tree. Am. J. Bot. 86:688-696.

- 2000. Computing factors of safety against windinduced tree stem damage. J. Exp. Bot. 51:797-806.

Niklas, K.J., and H.-C. Spatz. 1999. Methods for calculating factors of safety for plant stems. J. Exp. Biol. 202:3273-3280.

- 2000. Wind-induced stresses in cherry trees: Evidence against the hypothesis of constant stress levels. Trees, Struct. Func. 14:230-237.

Niklas, K.J., and T. Speck. 2001. Evolutionary trends in safety factors against wind-induced stem failure. Am. J. Bot. 88:36-48.

Niklas, K.J., J.Varna, and L.A. Berglund. 1999. Non-parametric statistical formulas for factors of safety of plant stems. J. Theoret. Biol. 197:135-147.

Niklas, K.J., F. Molina-Freaner, C. Tinoco-Ojanguren, and D.J. Paolillo, Jr. 2002. The biomechanics of Pachycereus pringlei root systems. Am. J. Bot. 89:12-21.

Vogel, S. 1981. Life in Moving Fluids. Willard Grant, Boston, MA. 352 pp.

Wainwright, S.A., W.D. Biggs, J.D. Currey, and J.M. Gosline. 1976. Mechanical Design in Organisms. John Wiley and Sons, New York, NY. 423 pp.

Weibull, W. 1939. A Statistical Theory of the Strength of Materials. Royal Swedish Institute, Stockholm, Sweden. 328 pp.

Department of Plant Biology

Cornell University

Ithaca, NY 14953, U.S. 
Résumé. Pour se maintenir et survivre dans n'importe quel environnement, un arbre doit être mécaniquement efficace et atteindre un facteur raisonnable de sécurité. Ce facteur de sécurité, qui doit s'ajuster durant les diverses phases de développement de l'arbre, peut être calculé pour les tiges (tronc et branches principales) et les racines en se basant sur le quotient des capacités de charge et de travail mécanique de chaque partie. Cette méthode est illustrée pour les tiges de cerisiers tardifs (Prunus serotina) et pour le système racinaire d'un cactus arborescent colonnaire (Pachycereus pringlei). Le facteur de sécurité des différentes parties diminue avec l'augmentation en dimension de la plante. La susceptibilité des tiges et des racines à des bris mécaniques s'accroît donc avec l'augmentation en masse ou en hauteur. Néanmoins, le risque de bris par le vent est amenuisé dans le cas des cerisiers tardifs par le bris sélectifs de plus petites branches périphériques, ce qui réduit les forces globales de traction et les mouvements de flexion des troncs. Dans le cas du cactus colonnaire, la demande racinaire en eau pour l'absorption et le stockage - prend préséance sur l'ancrage au fur et à mesure que les plantes grandissent. Ces deux cas d'études illustrent qu'une collection de facteurs de sécurité doivent être pris en compte et classés simultanément en termes de probabilité de dommage ou de mortalité pour différents risques de facteurs environnementaux.

Zusammenfassung. Um in einem bestimmten Umfeld überleben zu können, muß ein Baum mechanisch standsicher sein und einen gründlichen Sicherheitsfaktor erreicht haben. Dieser Sicherheitsfaktor, welcher sich Pflanzenwachstum orientieren muß, kann für Stämme und Wurzeln basierend auf dem Quotienten der Arbeitslast und dem Lasteintrag jedes einzelnen Ocomputer dargestellt werden. Diese Methode wurde hier für die Stämme von Kirschbäumen und das Wurzelsystem eines baumgleichen Kaktus illustriert, die in der Größe variieren. Der
Sicherheitsfaktor der Organe sinkt mit wachsender Pflanzengröße. Die Anfälligkeit der Stämme und Wurzeln für mechanisches Versagen wächst demnach mit Massen- oder Höhenwachstum. Trotzdem ist das Risiko des Windbruchs im Fall der Kirsche durch das selektive Windversagen kleiner peripherer Äste, welche die Gesamtwindanfälligkeit reduzieren und Biegeverhalten des Stammes verbessern. Im Falle des Säulenkaktus nimmt das Verlangen nach Wurzelwasseraufnahme Oberhand gegenüber der Verankerung wenn die Pflanze an Masse zunimmt. Diese beiden Fallstudien illustrieren, dass vielfailtige Sicherheitsfaktoren in Betracht gezogen und eingereiht werden müssen in Bezug auf die Schadenswahrscheinlichkeit oder Absterben aufgrund verschiedener Umweltrisiken.

Resumen. Para persistir y supervivir en cualquier ambiente, un árbol debe ser mecánicamente confiable y lograr un factor razonable de seguridad. Este factor de seguridad, el cual debe ser ajustado en el curso del crecimiento de la planta, puede ser calculado para ramas y raíces con base en un cuociente de la carga de trabajo y la capacidad de cada órgano. Este método es ilustrado para las ramas de árboles de cerezo (Prunus serotina) y para los sistemas de raíces de un cactus columnar arborescente (Pachycereus pringlei) diferentes en tamaño. El factor de seguridad de estos órganos disminuyó con el incremento en el tamaño de la planta. Sin embargo, la falla inducida por el viento es reducida en el caso de los cerezos mediante la selección de ramas pequeñas periféricas, lo cual disminuye las fuerzas y momentos actuantes sobre el tronco. En el caso del cactus columnar, la demanda de agua por las raíces para almacenaje/absorción es importante para el anclaje a medida que la planta crece en tamaño. Estos dos casos de estudio ilustran que los factores principales de seguridad deben ser considerados y clasificados simultáneamente en términos de la probabilidad de daño o muerte para diferentes factores ambientales de riesgo. 